\title{
Summary of the Statement on International Travellers Who Intend to Visit Friends and Relatives
}

\author{
Brophy $\mathrm{J}^{1}$ on behalf of the Committee to Advise on Tropical Medicine and Travel (CATMAT)*
}

${ }^{1}$ Children's Hospital of Eastern Ontario, Ottawa, ON

*Correspondence: CATMAT.Secretariat@phac-aspc.gc.ca

\begin{abstract}
Background: Travellers intending to visit friends and relatives (VFRs) are a specific group of travellers who have been identified as having an increased risk of travel-related morbidity.

Objective: To provide recommendations for risk reduction in international VFRs.

Methods: Recommendations regarding VFRs were developed based on available travel medicine literature and CATMAT expert opinion. Specific travel-related risks, including infectious disease epidemiology and burden in this population, were reviewed and recommendations were provided to attempt to mitigate these risks. Previous CATMAT statements related to VFRs were referred to and reiterated.
\end{abstract}

Recommendations: Rates of travel-related illness in VFRs tend to be higher for many conditions. Diseasespecific risk factors and recommendations are discussed throughout this Statement. CATMAT recommends that VFRs' vaccinations be up-to-date and they be counselled on the importance of various risk reduction activities such as the use of malaria prophylaxis, safe sex practices and injury prevention. Pre- and/or post-travel tuberculosis testing is indicated in certain situations.

Conclusion: The pre-travel health assessment is an important opportunity to address with VFRs issues regarding health beliefs, health behaviours, current health status and the possibility of pre-existing conditions. Discussions addressing the importance of adherence to health advice and potential challenges to achieving adherence may be necessary.

\section{Preamble}

The Committee to Advise on Tropical Medicine and Travel (CATMAT) provides the Public Health Agency of Canada with ongoing and timely medical, scientific, and public health advice relating to tropical infectious disease and health risks associated with international travel. The Agency acknowledges that the advice and recommendations set out in this statement are based upon the best current available scientific knowledge and medical practices and is disseminating this document for information purposes to both travellers and the medical community caring for travellers.

Persons administering or using drugs, vaccines or other products should also be aware of the contents of the product monograph(s) or other similarly approved standards or instructions for use. Recommendations for use and other information set out herein may differ from that set out in the product monograph(s) or other similarly approved standards or instructions for use by the licensed manufacturer(s). Manufacturers have sought approval and provided evidence as to the safety and efficacy of their products only when used in accordance with the product monographs or other similarly approved standards or instructions for use. 


\section{Introduction}

In 2012, visiting friends and relatives was the second most common reason for international travel among Canadian travellers and accounted for approximately two million overnight visits to overseas countries (1). Travellers intending to visit friends and relatives (VFRs) are a specific group identified as having an increased risk of travel-related morbidity. The United States Centers for Disease Control and Prevention define a VFR as "an immigrant, ethnically and racially distinct from the majority population of the country of residence (a higher-income country), who returns to his or her home country (lower-income country) to visit friends or relatives. Included in the VFR category are family members, such as the spouse or children who were born in the country of residence" (2).

This is a summary of the CATMAT Statement on International Travellers Who Intend to Visit Friends and Relatives, in which a full description of the evidence and recommendations is available (3). The Statement focuses on the abovementioned definition of VFRs and outlines the increased risks faced by VFRs while providing recommendations based on the available literature. Given the current global patterns of population mobility, this definition of VFR may be rather strict. It is reasonable to extend these recommendations to all travellers to any country with an epidemiological gradient of risk compared to the country of residence, whose intent is to visit friends and relatives, regardless of migrant status or ethnicity $(4,5)$.

\section{Methods}

A literature search was conducted for both published studies and grey literature. MEDLINE, EMBASE, Global Health, Scopus, Google Scholar and Access MEDLINE databases were used as well as reports and publications from Statistics Canada, the Public Health Agency of Canada (PHAC) and Citizenship and Immigration Canada.

Based on this initial overview, section topics were selected and additional focused literature searches were performed. Literature and evidence from Canada regarding the epidemiology and burden of specific diseases in the VFR population was used when available. The Statement does not contain a comprehensive overview of all travel-related risks, as content was prioritized based on increased risk specifically for VFRs. Therefore, it is important to be familiar with and address all travel-related risks at destination with a special emphasis on the topics discussed below.

The Statement represents a narrative review of the travel medicine literature on VFRs as well as CATMAT expert opinion. The recommendations do not include a description of the strength of the recommendation or grade of the quality of evidence as in previous CATMAT statements. Previous CATMAT statements were referred to and reiterated where they related to VFRs and a comprehensive list of current CATMAT statements can be found on the PHAC travel health website (6).

\section{Results and recommendations}

\section{Risk factors}

Rates of travel-related illness in VFRs tend to be higher for many conditions due to several factors. VFRs have an increased potential for last-minute travel plans, often have longer stays, may be reluctant to eat differently than hosts, may stay in places without door or window screens and without bed nets, are often in close proximity to the local population and have an increased likelihood of drinking untreated water $(7,8)$.

VFRs and foreign-born travellers are less likely to seek pre-travel health consultation $(9,10,11,12)$, are more likely to seek advice closer to departure (13) and are more likely to decline a recommended vaccine (13). These differences have been associated with VFRs' low perception of personal disease risk (8), but may also reflect language, cultural and/or financial barriers preventing uptake $(14,15)$. VFRs often believe that they are immune to diseases (such as malaria) in their home country $(7,14,16)$. They may seek advice from health care providers with a similar ethnic background who may not recommend preventive strategies such as chemoprophylaxis due to similar beliefs $(17,18)$. 


\section{Malaria}

Studies have found that among travellers with malaria, 59 to $99 \%$ did not use malaria chemoprophylaxis or took it inadequately (inappropriate drug or adherence) (19). In a Canadian case series of malaria diagnoses, the majority of cases were among travellers who did not seek pre-travel advice and/or did not take appropriate malaria prophylaxis $(20,21)$.

VFRs account for a significant proportion of imported malaria cases in non-endemic countries (19). Studies have found foreign-born VFRs to have up to a 4.5-fold higher risk of contracting malaria than tourist travellers (22). Based on data from the Canadian Malaria Network from 2001 to 2013, 45\% of severe malaria cases in Canada, for which information was available, reported visiting friends and relatives as the purpose for travel (23).

Given the characteristics mentioned above that may increase the risk of malaria (such as personal perception of disease risk and immunity) VFRs should be counselled about the importance of malaria prevention when travelling to malaria-endemic countries. Recommendations should include use of personal protective measures to prevent mosquito bites and potential use of chemoprophylaxis, depending upon destination. VFRs should be advised to seek health care if they develop fever during travel or once they return to Canada.

Specific recommendations on malaria chemoprophylaxis are available in CATMAT's Canadian Recommendations for the Prevention and Treatment of Malaria (24).

\section{Vaccine-preventable diseases}

Due to variation in vaccination schedules or lack of access to vaccines in different countries, Canadian immigrants may be more susceptible to vaccine-preventable disease.

\section{Routine immunization}

Studies have found substantial rates of non-immunity to measles, mumps, rubella and varicella among Canadian immigrants from developing countries $(25,26,27)$. Foreign-born VFRs should be evaluated for immunization status and immunity to vaccine-preventable disease and routine vaccinations should be provided as needed. For pediatric VFRs, there may be an opportunity to accelerate the routine schedule in order to provide maximal protection during travel.

Appendix 2 in the full VFR Statement (3) and CATMAT's Statement on Pediatric Travellers (28) contain information on accelerated vaccination schedules for children.

\section{Typhoid}

The majority of cases of typhoid fever in North America are associated with travel, particularly travel to South Asia (Afghanistan, Pakistan, India, Nepal, Bangladesh, Maldives, Sri Lanka and Bhutan) (15). Studies have found VFR travel to be a major risk factor for travel-related typhoid fever infection, with VFRs accounting for $66 \%$ of cases in the United States (29) and more than $90 \%$ of cases in Quebec (30). A study by the global GeoSentinel network found VFRs to have a 7-fold greater risk of receiving a diagnosis of typhoid fever compared with tourist travellers (22).

Age-appropriate typhoid vaccination is recommended for VFRs travelling to South Asia (31). Typhoid vaccine is not routinely recommended for travellers to destinations outside of South Asia; however, it may be considered for VFRs in specific high-risk situations (31). Safe food and water precautions should be discussed and the importance of frequent hand washing should be emphasized.

Refer to CATMAT's Statement on International Travellers and Typhoid (31) for further information on prevention of typhoid fever and use of typhoid vaccine.

\section{Hepatitis $A$ and $B$}

VFRs, especially children, are a major contributor to hepatitis A cases in Europe and North America. Studies from Europe and Quebec have found that VFRs account for $28 \%-78 \%$ of travel-related HA cases $(30,32,33,34,35)$.

Research has shown that over half of immigrants and refugees are non-immune to hepatitis $B(36)$. Several behavioural characteristics of VFR travel (longer periods in country, close contact with local population, greater 
risk of injury and/or contact with the medical system) and high levels of non-immunity would be considered specific risk factors for hepatitis $B$ acquisition.

Those travelling to countries with poor sanitation and hygiene conditions should be advised to follow safe food and water precautions and to wash their hands frequently (37). VFRs travelling to HB-endemic countries or who may engage in behaviours increasing their risk for blood/body fluid contact should be counselled regarding safe practices (condom use, use of sterile medical equipment) (38). Travellers who are non-immune to HA and/or HB should be vaccinated prior to travel (37). Age-appropriate immunization is advised for children.

Further recommendations on prevention of HA and HB in travellers can be found in CATMAT's Summary of Recommendations for the Prevention of Viral Hepatitis During Travel (37).

\section{Tuberculosis}

Travellers to countries with higher tuberculosis (TB) incidence are at risk of acquiring infection during travel. Foreign-born individuals accounted for $64 \%$ of all reported cases in Canada in 2012, with the highest incidence rates among those originating from Africa, South-East Asia, Western Pacific and Eastern Mediterranean (39). These cases include TB disease acquired in the country of origin before immigration as well as during return VFR trips. Studies have found that significant proportions of TB in immigrant populations can be attributed to VFR travel $(40,41)$. Additionally, foreign travel, especially VFR travel, has been found to be a risk factor for latent TB infection (LTBI) $(42,43)$.

VFRs travelling to high TB incidence countries should avoid consumption of unpasteurized dairy products to reduce the risk of $M$. bovis acquisition (44). VFRs should be cautioned to avoid individuals with unexplained chronic cough or known pulmonary TB until the individual is deemed non-infectious. Bacillus Calmette-Guérin (BCG) vaccine may be considered in certain circumstances for individual long-term travellers to high-prevalence countries (45).

Pre- and/or post-travel TB skin tests may be indicated depending on risk at destination, duration of travel and personal health factors. The full VFR Statement contains a decision making model to guide TB skin testing in travellers (3).

Refer to CATMAT's Risk Assessment and Prevention of Tuberculosis Among Travellers (44) for detailed guidance on pre-travel advice for TB infection risk avoidance and post-travel TB screening and to the Canadian

Tuberculosis Standards (45) for up-to-date information on TB risk conditions and country-level risk stratification.

\section{Parasitic infections}

Certain parasitic infections, such as schistosomiasis, strongyloidiasis, echinococcosis and cysticercosis can be chronic and may cause significant morbidity and even death, while others are self-limiting and have a low impact on health. A Canadian GeoSentinel study found VFRs to be more likely to present with these and other parasitic infections (46).

VFRs should be advised to avoid freshwater activities (such as swimming) in regions where schistosomiasis is endemic (Africa, South-East Asia and parts of South America). Avoidance of skin-to-soil contact (such as walking barefoot) is recommended to prevent strongyloidiasis in tropical countries. Food and water precautions are recommended to prevent other parasitic infections spread via the fecal-oral route. The pre-travel assessment can provide an opportunity to identify risk and recommend screening for these treatable chronic parasitic infections among immigrants.

\section{Sexually transmitted infections and Human Immunodeficiency Virus}

New sexual partners and unprotected sexual encounters are common among travellers generally (47), including VFRs $(48,49)$. A recent global GeoSentinel review found that VFR travel was associated with an increased risk of sexually transmitted infections (STI) compared with other travel (50) which adds to existing literature reports that STIs were more likely among VFRs than other travellers $(22,51)$. 
Sexual health counselling should be a routine part of the pre-travel consultation and risk of exposure to STIs and Human Immunodeficiency Virus (HIV) should be discussed. The importance of safer sex practices should be emphasized and travellers should be encouraged to bring condoms from Canada to assure their quality (52). HPV vaccine can be considered for adolescent and adult travellers not previously vaccinated. HB vaccination is recommended as above.

Refer to CATMAT's Statement on Travellers and Sexually Transmitted Infections (52) for additional recommendations related to STI risk reduction.

\section{Injury}

Injury is a significant cause of morbidity and mortality in travellers and accounts for $18 \%-25 \%$ of traveller mortality abroad $(53,54,55)$. Numerous characteristics of VFRs (longer trip duration, greater likelihood to use local modes of travel) are assumed to increase injury risk, though there is not specific literature on travel-related injury among VFRs.

Road safety precautions such as seatbelts, infant/child car seats and helmets should be recommended (56). VFRs should avoid riding motorcycles or bicycles and should be encouraged to use helmets where this cannot be avoided (56). For more information on injury risk and recommendations for prevention, refer to CATMAT's Statement on Risk of Injury and Travel (56).

\section{Special populations}

\section{Pediatric VFRs}

Compared to pediatric tourist travellers, pediatric VFRs are more likely to be younger, travel for longer periods, travel more often to rural areas, present for pre-travel advice closer to the departure date and travel to destinations with higher risk for tropical diseases $(57,58)$.

Pediatric VFRs have an increased risk of travel-related illness and are at particular risk for febrile illness (especially caused by malaria) (59), TB, typhoid and meningococcal meningitis (60). A recent surveillance study of pediatric VFRs from Canada found that enteric fever, malaria, diarrheal diseases and HA accounted for $75 \%$ of travel-related illnesses in this group (61). Only $26 \%$ of these travellers had received pre-travel advice.

These results emphasize the importance of pre-travel assessment and adherence to recommended interventions for children. Opportunities to accelerate the routine schedule should be evaluated in order to provide maximal protection during travel (refer to Appendix 2 of the full VFR Statement (3) for accelerated vaccination schedules) Parents should be advised that the rates of illness requiring hospitalization are higher among VFR children and that illness during and after travel requires urgent assessment. Also, parents of Canadian-born VFR children should be informed that their children do not have any innate immunity against travel-related illnesses due to genetics alone. For more information on pediatric travellers and recommendations, refer to CATMAT's Statement on Pediatric Travellers (28).

\section{Immunocompromised and older VFRs}

There is little research focusing on immunocompromised or older VFRs. Specific characteristics of these populations (comorbid conditions, poorer immune responses, contraindications to vaccines or frailty) which lead to increased health risks while travelling may lead to synergistic risks for VFRs.

Infectious disease risk should be reviewed with the traveller according to the degree of their immune compromise along with risks specific to the destination and appropriateness of travel.

For travel health information on immunocompromised travellers and detailed recommendations on specific conditions, refer to CATMAT's Statement on The Immunocompromised Traveller (62). For information on and recommendations for older travellers, refer to CATMAT's Statement on Older Travellers (63). 


\section{Targeting VFRs for pre-travel advice}

Health care providers should discuss potential upcoming VFR travel with their patients at routine health visits. Consultation with a travel health specialist should be recommended for all VFRs and particularly for those with risk factors for severe disease. Because some patients may be unwilling or unable to afford the cost of seeking travel medicine consultation, primary care providers should equip themselves with travel health knowledge and clinical resources so they are able to provide appropriate essential recommendations.

\section{Conclusion}

The pre-travel consultation for VFRs provides an important opportunity for health promotion, identification of preexisting conditions and risk reduction. VFRs should be made aware of their increased risk for travel-related illnesses and how to prevent them. Higher levels of non-immunity to vaccine-preventable disease and increased prevalence of chronic diseases among VFRs should also be addressed. In addition, health care providers should stress the importance of adherence and address potential challenges to achieving it.

Table 1 summarizes the disease-specific recommendations for VFRs and additional resources. Additional research is required to determine the facilitators and barriers for VFRs in accessing and adhering to pre-travel advice. Engaging ethnic communities and health care personnel that provide their care is necessary to assess knowledge, attitudes and behaviour regarding travel health and to determine optimal ways of providing information to VFRs.

\section{Table 1: Disease-specific recommendations for visiting friends and relatives (VFR) and additional} resources

\begin{tabular}{|c|c|c|}
\hline Disease & $\begin{array}{l}\text { Strategies to decrease travel-associated risk } \\
\text { to VFRs }\end{array}$ & Resources for further information \\
\hline Malaria & $\begin{array}{l}\text { - } \quad \text { Targeted counselling including correction of } \\
\text { personal risk misconceptions (e.g., traveller } \\
\text { believes they are immune). } \\
\text { - } \quad \text { Advise personal protective measures } \\
\text { against mosquito bites, chemoprophylaxis } \\
\text { may be indicated. } \\
\text { - Where antimalarial chemoprophylaxis is } \\
\text { indicated, VFRs should be encouraged to } \\
\text { purchase it within Canada rather than } \\
\text { abroad. } \\
\text { VFRs travelling to malaria-endemic regions } \\
\text { should be advised to seek health care if } \\
\text { they develop fever during or after travel. }\end{array}$ & $\begin{array}{l}\text { - CATMAT's Canadian } \\
\text { Recommendations for the } \\
\text { Prevention and Treatment of } \\
\text { Malaria (24) } \\
\text { - CATMAT's Statement on } \\
\text { Personal Protective Measures } \\
\text { to Prevent Arthropod Bites (64) } \\
\text { - Children: CATMAT's Statement } \\
\text { on Pediatric Travellers (28) }\end{array}$ \\
\hline $\begin{array}{l}\text { Routine } \\
\text { vaccine- } \\
\text { preventable } \\
\text { disease }\end{array}$ & $\begin{array}{l}\text { Evaluate immunization status of foreign- } \\
\text { born individuals and update routine } \\
\text { vaccinations as necessary. } \\
\text { Children: Possible acceleration of primary } \\
\text { immunization series should be evaluated to } \\
\text { provide maximal protection during travel. }\end{array}$ & $\begin{array}{l}\text { - } \quad \text { Appendix } 2 \text { of the full VFR } \\
\text { Statement, pediatric } \\
\text { accelerated immunization } \\
\text { schedules table (3) } \\
\text { - CATMAT's Statement on } \\
\text { Pediatric Travellers (28) } \\
\text { - Canadian Immunization Guide } \\
\text { Part 3, Immunization of } \\
\text { Travellers (65) }\end{array}$ \\
\hline Typhoid & $\begin{array}{l}\text { Those travelling to countries with poor } \\
\text { sanitation and hygiene conditions should be } \\
\text { advised to follow safe food and water } \\
\text { precautions and to wash their hands } \\
\text { frequently. } \\
\text { - Typhoid vaccine is recommended for adult } \\
\text { and children (where age-appropriate) }\end{array}$ & $\begin{array}{l}\text { - } \\
\text { CATMAT's Statement on } \\
\text { International Travellers and } \\
\text { Typhoid (31) }\end{array}$ \\
\hline
\end{tabular}




\begin{tabular}{|c|c|c|}
\hline & $\begin{array}{l}\text { travelling to South } \text { Asia }^{1}(31) \text {. } \\
\text { Typhoid vaccine is not routinely } \\
\text { recommended for travellers to destinations } \\
\text { other than South Asia }{ }^{1} \text {; however, it may be } \\
\text { considered for VFRs in situations posing } \\
\text { significant risk (e.g., children, extended } \\
\text { periods of stay, inability to avoid high-risk } \\
\text { food/water exposures) (31). }\end{array}$ & \\
\hline Hepatitis A (HA) & $\begin{array}{l}\text { Travellers should be advised to follow safe } \\
\text { food and water precautions and to wash } \\
\text { their hands frequently. } \\
\text { - Non-immune VFRs going to developing } \\
\text { countries should be vaccinated. } \\
\text { Children: Age-appropriate immunization } \\
\text { against HA is advised for children. }\end{array}$ & $\begin{array}{l}\text { - CATMAT's Statement on } \\
\text { Hepatitis Vaccines for } \\
\text { Travellers (38) } \\
\text { - CATMAT's Summary of } \\
\text { Recommendations for the } \\
\text { Prevention of Viral Hepatitis } \\
\text { During Travel (37) }\end{array}$ \\
\hline Hepatitis B (HB) & $\begin{array}{l}\text { - All VFRs going to countries endemic for HB } \\
\text { (i.e., with HB surface antigen prevalence } \geq \\
2 \% \text { ) or who may engage in behaviours } \\
\text { increasing their risk for blood/body fluid } \\
\text { contact should be counselled regarding } \\
\text { safe practices (condom use, use of sterile } \\
\text { medical equipment). } \\
\text { - Non-immune VFRs should be vaccinated. } \\
\text { - Children: Age-appropriate immunization } \\
\text { against HB is advised for children. }\end{array}$ & $\begin{array}{ll}\text { - } & \text { CATMAT's Statement on } \\
\text { Hepatitis Vaccines for } \\
\text { Travellers (38) } \\
\text { - CATMAT's Summary of } \\
\text { Recommendations for the } \\
\text { Prevention of Viral Hepatitis } \\
\text { During Travel (37) } \\
\text { - World Health Organization map } \\
\text { of endemic countries (66) }\end{array}$ \\
\hline $\begin{array}{l}\text { Tuberculosis } \\
\text { (TB) }\end{array}$ & $\begin{array}{l}\text { VFRs should avoid contact with individuals } \\
\text { who have known pulmonary TB (while they } \\
\text { remain infectious) or people with } \\
\text { unexplained chronic cough. } \\
\text { Pre- and/or post-travel TB skin tests may } \\
\text { be indicated depending on risk at } \\
\text { destination, duration of travel and personal } \\
\text { health factors. The full VFR Statement } \\
\text { contains a decision model to guide TB skin } \\
\text { testing in travellers (3). } \\
\text { In some exceptional circumstances BCG } \\
\text { may be considered for individual long-term } \\
\text { travellers to high-prevalence countries. } \\
\text { VFRs travelling to high TB incidence } \\
\text { countries should avoid consumption of } \\
\text { unpasteurized dairy products to avoid the } \\
\text { risk of M. bovis acquisition. }\end{array}$ & $\begin{array}{l}\text { - Appendices 3, } 4 \text { and 5, criteria } \\
\text { for TB skin testing post-travel, } \\
\text { risk factors for development of } \\
\text { active TB and decision making } \\
\text { model to guide TB skin testing } \\
\text { (3) } \\
\text { CATMAT's Risk Assessment } \\
\text { and Prevention of Tuberculosis } \\
\text { Among Travellers (44) } \\
\text { The Canadian Tuberculosis } \\
\text { Standards (Chapters } 6 \text { \& 13) } \\
\text { (45) } \\
\text { Children: CATMAT's Statement } \\
\text { on Pediatric Travellers (28) }\end{array}$ \\
\hline $\begin{array}{l}\text { Parasitic } \\
\text { infections }\end{array}$ & $\begin{array}{l}\text { Travellers should be advised to avoid } \\
\text { freshwater activities, such as swimming, in } \\
\text { Africa, South-East Asia and parts of South } \\
\text { America to prevent schistosomiasis } \\
\text { - Avoid walking barefoot or other skin-to-soil } \\
\text { contacts in tropical countries to prevent } \\
\text { strongyloidiasis. } \\
\text { - Follow safe food and water precautions for } \\
\text { prevention of various intestinal parasitic } \\
\text { infections. }\end{array}$ & \\
\hline $\begin{array}{l}\text { Sexually } \\
\text { transmitted }\end{array}$ & $\begin{array}{l}\text { - Discuss sexual activity during travel and the } \\
\text { rates of STIs and HIV in the general and }\end{array}$ & $\begin{array}{l}\text { - } \quad \text { CATMAT's Statement on } \\
\text { Travellers and Sexually }\end{array}$ \\
\hline
\end{tabular}




\begin{tabular}{|c|c|c|}
\hline $\begin{array}{l}\text { infections (STIs) } \\
\text { and Human } \\
\text { Immunodeficien } \\
\text { cy Virus (HIV) }\end{array}$ & $\begin{array}{l}\text { sex worker populations at destination. } \\
\text { Stress the importance of safer sex practices } \\
\text { and preparation for travel by bringing } \\
\text { condoms from Canada (to ensure quality). } \\
\text { - HB vaccination should be recommended as } \\
\text { above. } \\
\text { HPV vaccine can be considered for } \\
\text { adolescent and adult travellers not } \\
\text { previously vaccinated. }\end{array}$ & Transmitted Infections (52) \\
\hline Injury & $\begin{array}{l}\text { VFRs should avoid the use of bicycles and } \\
\text { motorcycles and use helmets if these } \\
\text { activities cannot be avoided. } \\
\text { Encourage standard road safety } \\
\text { precautions such as seat belts and } \\
\text { infant/child car seats. }\end{array}$ & $\begin{array}{l}\text { - CATMAT's Statement on Risk } \\
\text { of Injury and Travel (56) }\end{array}$ \\
\hline $\begin{array}{l}\text { Pediatric } \\
\text { travellers }\end{array}$ & $\begin{array}{l}\text { - Counsel parents that rates of illness } \\
\text { requiring hospitalization are higher among } \\
\text { VFR children and that illness during and } \\
\text { after travel requires urgent assessment. } \\
\text { - Address misconceptions around prior } \\
\text { immunity (e.g., child is not protected } \\
\text { because parent was born in destination } \\
\text { country). } \\
\text { - Accelerated vaccination may be possible. } \\
\text { - Post-travel TB skin testing and BCG } \\
\text { vaccination may be indicated in specific } \\
\text { situations, see additional resources for } \\
\text { recommendations. }\end{array}$ & $\begin{array}{l}\text { - } \text { Child-specific } \\
\text { recommendations in previous } \\
\text { sections, including in } \\
\text { CATMAT's Canadian } \\
\text { Recommendations for the } \\
\text { Prevention and Treatment of } \\
\text { Malaria (24) } \\
\text { - Appendix } 2 \text { for accelerated } \\
\text { vaccination schedule (3) } \\
\text { CATMAT's Statement on } \\
\text { Pediatric Travellers (28) } \\
\text { CATMAT's Risk Assessment } \\
\text { and Prevention of Tuberculosis } \\
\text { Among Travellers (44) } \\
\text { The Canadian Tuberculosis } \\
\text { Standards (Chapters } 6 \& 13) \\
\text { (45) }\end{array}$ \\
\hline Older travellers & $\begin{array}{l}\text { Review of comorbidities and vaccine } \\
\text { recommendations according to age should } \\
\text { be conducted. } \\
\text { - Pre- and/or post-travel TB skin testing may } \\
\text { be indicated. }\end{array}$ & $\begin{array}{ll}- & \text { CATMAT's Statement on Older } \\
\text { Travellers (63) } \\
\text { - CATMAT's Risk Assessment } \\
\text { and Prevention of Tuberculosis } \\
\text { Among Travellers (44) } \\
\text { - The Canadian Tuberculosis } \\
\text { Standards (Chapters } 6 \text { \& 13) } \\
\text { (45) }\end{array}$ \\
\hline $\begin{array}{l}\text { Immunocompro } \\
\text { mised travellers }\end{array}$ & $\begin{array}{l}\text { - Review infection risk for travellers } \\
\text { according to personal immune compromise } \\
\text { and risk at destination and discuss } \\
\text { appropriateness of travel. } \\
\text { - Post-travel TB skin testing may be } \\
\text { indicated. }\end{array}$ & $\begin{array}{l}\text { - CATMAT's Statement on The } \\
\text { Immunocompromised Traveller } \\
\text { (62) } \\
\text { - CATMAT's Risk Assessment } \\
\text { and Prevention of Tuberculosis } \\
\text { Among Travellers (44) } \\
\text { - The Canadian Tuberculosis } \\
\text { Standards (Chapters } 6 \& 13 \text { ) } \\
\text { (45) }\end{array}$ \\
\hline
\end{tabular}




\section{Acknowledgements}

This summary was developed by the VFR Working Group: Brophy J (Chair), Bui Y, Crockett M, Greenaway C, McCarthy A, Jagt K, Geduld J and Bryson M.

CATMAT Members: McCarthy A (Chair), Boggild A, Brophy J, Bui Y, Crockett M, Ghesquiere W, Greenaway C, Henteleff A, Libman M, Teitelbaum P, Vaughan S.

Liaison members: Hui C (Canadian Paediatric Society), Gershman M (US Centers for Disease Control and Prevention), Pernica J (Association of Medical Microbiology and Infectious Disease Canada).

Ex-officio members: McDonald P (Division of Anti-Infective Drugs, Health Canada), Tepper M (Directorate of Force Health Protection, Department of National Defence), Schofield S (Directorate of Force Health Protection, Department of National Defence), Marion D (Canadian Forces Health Services Centre, Department of National Defence).

Member Emeritus: Jeanes CWL. (Until June 2014)

\section{Conflict of interest}

None.

\section{Funding}

This work was supported by the Public Health Agency of Canada.

\section{References}

(1) Statistics Canada. International Travel Survey, Canadian Residents 2012. Custom extract for the Public Health Agency of Canada.

(2) Centers for Disease Control and Prevention. CDC Health Information for International Travel 2014. New York: Oxford University Press; 2014.

(3) Committee to Advise on Tropical Medicine and Travel. Statement on International Travellers Who Intend to Visit Friends and Relatives. 2015. http://www.phac-aspc.gc.ca/tmp-pmv/catmat-ccmtmv/friends-amis-eng.php

(4) Barnett ED, MacPherson DW, Stauffer WM, Loutan L, Hatz CF, Matteelli A, et al. The visiting friends or relatives traveler in the 21st century: Time for a new definition. J Travel Med. 2010 May-Jun;17(3):163-170.

(5) Behrens RH, Stauffer WM, Barnett ED, Loutan L, Hatz CF, Matteelli A, et al. Travel case scenarios as a demonstration of risk assessment of VFR travelers: Introduction to criteria and evidence-based definition and framework. J Travel Med. 2010 May-Jun;17(3):153-162.

(6) Public Health Agency of Canada. About CATMAT. 2014. http://www.phac-aspc.gc.ca/tmp-pmv/catmat-ccmtmv/index-eng.php.

(7) Bacaner N, Stauffer B, Boulware DR, Walker PF, Keystone JS. Travel medicine considerations for North American immigrants visiting friends and relatives. JAMA. 2004 Jun 16;291(23):2856-2864.

(8) Angell SY, Cetron MS. Health disparities among travelers visiting friends and relatives abroad. Ann Intern Med 2005 Jan 4;142(1):67-72.

(9) Baggett HC, Graham S, Kozarsky PE, Gallagher N, Blumensaadt S, Bateman J, et al. Pretravel health preparation among US residents traveling to India to VFRs: Importance of ethnicity in defining VFRs. J Travel Med. 2009 MarApr;16(2):112-118.

(10) LaRocque R, Rao S, Lawton T, Tsibris A, Schoenfeld D, Barry A, et al. Use and sources of medical information among departing international travelers to low and middle income countries at Logan International Airport-Boston, MA, 2009. Int J Inf Dis. Conference: 14th International Congress on Infectious Diseases (ICID) Miami, FL United States.Conference 2010 March 2010;14:e132.

(11) Van Herck K, Van Damme P, Castelli F, Zuckerman J, Nothdurft H, Dahlgren AL, et al. Knowledge, attitudes and practices in travel-related infectious diseases: The European Airport Survey. J Travel Med. 2004 Jan-Feb;11(1):3-8.

(12) Van Genderen PJ, Van Thiel PP, Mulder PG, Overbosch D. Trends in the knowledge, attitudes and practices of travel risk groups towards prevention of malaria: Results from the Dutch Schiphol Airport Survey 2002 to 2009. Malaria Journal. 2012;11.

(13) LaRocque RC, Deshpande BR, Rao SR, Brunette GW, Sotir MJ, Jentes ES, et al. Pre-travel health care of immigrants returning home to visit friends and relatives. Am J Trop Med Hyg. 2013;88(2):376-380. 
(14) Centers for Disease Control and Prevention (CDC). CDC Health Information for International Travel 2012. New York: Oxford University Press; 2012.

(15) Behrens RH, Barnett ED. Chapter 29: Visiting Friends and Relatives. In: Keystone JS, Kozarsky PE, Freedman DO, Nothdurft H, Connor BA, editors. Travel Medicine. Second ed. USA: Mosby Elsevier; 2008. p. 291-298.

(16) Angell SY, Behrens RH. Risk assessment and disease prevention in travelers visiting friends and relatives. Infect Dis Clin North Am. 2005 Mar;19(1):49-65.

(17) McCarthy M. Should visits to relatives carry a health warning? Lancet. 2001 Mar 17;357(9259):862.

(18) Campbell H. Imported malaria in the UK: Advice given by general practitioners to British residents travelling to malaria-endemic areas. J R Coll Gen Pract. 1987 Feb;37(295):70-72.

(19) Pavli A, Maltezou HC. Malaria and travellers visiting friends and relatives. Travel Med Infect Dis. 2010 May;8(3):161168.

(20) Fanella ST, Lipkin H, Crockett ME. Presentation of pediatric malaria to a Canadian Children's Hospital. J Travel Med. 2012;19(6):391-394.

(21) Lee CS, Gregson DB, Church D, Laupland KB, Eckhardt R, Ross T, et al. Population-based laboratory surveillance of imported malaria in Metropolitan Calgary, 2000-2011. PLoS One. 2013;8(4):e60751. http://www.ncbi.nlm.nih.gov/pubmed/?term=Populationbased+laboratory+surveillance+of+imported+malaria+in+Metropolitan+Calgary

(22) Leder K, Tong S, Weld L, Kain KC, Wildersmith A, von Sonnenburg F, et al. Illness in travelers visiting friends and relatives: A review of the GeoSentinel Surveillance Network. Clin Infect Dis. 2006 Nov 1;43(9):1185-1193.

(23) McCarthy AE, Morgan CA, Prematunge C, Geduld J. Severe malaria in Canada, 2001-2013. (In press).

(24) Committee to Advise on Tropical Medicine and Travel. Canadian Recommendations for the Prevention and Treatment of Malaria. 2014. http://publications.gc.ca/collections/collection_2014/aspc-phac/HP40-102-2014-eng.pdf.

(25) Greenaway C, Dongier P, Boivin JF, Tapiero B, Miller M, Schwartzman K. Susceptibility to measles, mumps and rubella in newly arrived adult immigrants and refugees. Ann Intern Med. 2007 Jan 2;146(1):20-24.

(26) Greenaway C, Boivin JF, Cnossen S, Rossi C, Tapiero B, Schwartzman K, et al. Risk factors for susceptibility to varicella in newly arrived adult migrants in Canada. Epidemiol Infect. 2013 Nov 1:1-13.

(27) Parkins MD, McNeil SA, Laupland KB. Routine immunization of adults in Canada: Review of the epidemiology of vaccine-preventable diseases and current recommendations for primary prevention. Can J Infect Dis Med Microbiol. 2009;20(3):e81-90.

(28) Committee to Advise on Tropical Medicine and Travel. Statement on Pediatric Travellers. Can Commun Dis Rep. 2010;ACS-3(36):1-31.

(29) Lynch MF, Blanton EM, Bulens S, Polyak C, Vojdani J, Stevenson J, et al. Typhoid fever in the United States, 19992006. JAMA. 2009;302(8):859-865.

(30) Bui Y, Trepanier S, Milord F, Blackburn M, Provost S, Gagnon S. Cases of malaria, hepatitis A and typhoid fever among VFRs, Quebec (Canada). J Travel Med. 2011 November-December 2011;18(6):373-378.

(31) Committee to Advise on Tropical Medicine and Travel. Statement on International Travellers and Typhoid. 2014. http://publications.gc.ca/collections/collection_2014/aspc-phac/HP40-98-2014-eng.pdf.

(32) Askling HH, Rombo L, Andersson Y, Martin S, Ekdahl K. Hepatitis A risk in travelers. J Travel Med. 2009 JulAug;16(4):233-238.

(33) Faber MS, Stark K, Behnke SC, Schreier E, Frank C. Epidemiology of hepatitis A virus infections, Germany, 20072008. Emerg Infect Dis. 2009 Nov;15(11):1760-1768.

(34) Mutsch M, Spicher VM, Gut C, Steffen R. Hepatitis A virus infections in travelers, 1988-2004. Clin Infect Dis. 2006 Feb 15;42(4):490-497.

(35) Nielsen US, Larsen CS, Howitz M, Petersen E. Hepatitis A among Danish travellers 1980-2007. J Infect. 2009 Jan;58(1):47-52.

(36) Rossi C, Shrier I, Marshall L, Cnossen S, Schwartzman K, Klein MB, et al. Seroprevalence of chronic hepatitis B virus infection and prior immunity in immigrants and refugees: A systematic review and meta-analysis. PLOS ONE. 2012;7(9).

(37) Committee to Advise on Tropical Medicine and Travel. Summary of recommendations for the prevention of viral hepatitis during travel. Can Commun Dis Rep. 2014;40(13):278-281.

(38) Committee to Advise on Tropical Medicine and Travel. Statement on Hepatitis Vaccines for Travellers. Can Commun Dis Rep. 2008;34(ACS-2):1-24.

(39) Public Health Agency of Canada. Tuberculosis in Canada 2012 - Pre-Release. 2012. http://www.phacaspc.gc.ca/tbpc-latb/pubs/tbcan12pre/index-eng.php.

(40) Ormerod LP, Green RM, Gray S. Are there still effects on Indian subcontinent ethnic tuberculosis of return visits?: A longitudinal study 1978-97. J Infect. 2001;43(2):132-134.

(41) Kik SV, Mensen M, Beltman M, Gijsberts M, Van Ameijden EJC, Cobelens FGJ, et al. Risk of travelling to the country of origin for tuberculosis among immigrants living in a low-incidence country. Int J Tuberc Lung D. 2011;15(1):38-43.

(42) Saiman L, San Gabriel P, Schulte J, Vargas MP, Kenyon T, Onorato I. Risk factors for latent tuberculosis infection among children in New York City. Pediatrics. 2001;107(5):999-1003. 
(43) Lobato MN, Hopewell PC. Mycobacterium tuberculosis infection after travel to or contact with visitors from countries with a high prevalence of tuberculosis. Am J Respir Crit Care Med. 1998 Dec;158(6):1871-1875.

(44) Committee to Advise on Tropical Medicine and Travel. Risk Assessment and Prevention of Tuberculosis Among Travellers. Can Commun Dis Rep. 2009;35(ACS-5):1-20.

(45) Public Health Agency of Canada. Canadian Tuberculosis Standards. 7th ed. Ottawa (ON): Public Health Agency of Canada, Canadian Lung Association/Canadian Thoracic Society; 2014.

(46) Boggild AK, Yohanna S, Keystone JS, Kain KC. Prospective analysis of parasitic infections in Canadian travelers and immigrants. J Travel Med. 2006 May-Jun;13(3):138-144.

(47) Vivancos R, Abubakar I, Hunter PR. Foreign travel, casual sex and sexually transmitted infections: systematic review and meta-analysis. Int J Infect Dis 2010 Oct;14(10):e842-51.

(48) Kramer MA, van den Hoek A, Coutinho RA, Prins M. Sexual risk behaviour among Surinamese and Antillean migrants travelling to their countries of origin. Sex Transm Infect. 2005 Dec;81(6):508-510.

(49) Fenton KA, Chinouya M, Davidson O, Copas A, MAYISHA research team. HIV transmission risk among sub-Saharan Africans in London travelling to their countries of origin. AIDS. 2001 Jul 27;15(11):1442-1445.

(50) Matteelli A, Schlagenhauf P, Carvalho ACC, Weld L, Davis XM, Wilder-Smith A, et al. Travel-associated sexually transmitted infections: An observational cross-sectional study of the GeoSentinel surveillance database. Lancet Infect Dis. 2013;13(3):205-213 2013.

(51) Fenner L, Weber R, Steffen R, Schlagenhauf P. Imported infectious disease and purpose of travel, Switzerland. Emerg Infect Dis. 2007 Feb;13(2):217-222.

(52) Committee to Advise on Tropical Medicine and Travel. Statement on Travellers and Sexually Transmitted Infections. Can Commun Dis Rep. 2006;32(ACS-5):1-24.

(53) Mclnnes RJ, Williamson LM, Morrison A. Unintentional injury during foreign travel: A review. J Travel Med. 2002 NovDec;9(6):297-307.

(54) Lunetta P. Injury deaths among Finnish residents travelling abroad. Int J Inj Contr Saf Promot. 2010 Sep;17(3):161168.

(55) MacPherson DW, Gushulak BD, Sandhu J. Death and international travel--the Canadian experience: 1996 to 2004 . J Travel Med. 2007 Mar-Apr;14(2):77-84.

(56) Committee to Advise on Tropical Medicine and Travel. Statement on Risk of Injury and Travel. Can Commun Dis Rep. 2010;36(ACS-13):1-14.

(57) Valerio L, Roure S, Sabria M, Balanzo Xd, Moreno N, MartinezCuevas O, et al. Epidemiologic and biogeographic analysis of 542 VFR traveling children in Catalonia (Spain). A rising new population with specific needs. J Travel Med. 2011;18(5): 304-309.

(58) Han P, Yanni E, Jentes ES, Hamer DH, Chen LH, Wilson ME, et al. Health challenges of young travelers visiting friends and relatives compared with those traveling for other purposes. Pediatr Infect Dis J. 2012;31(9):915-919.

(59) Hagmann S, Neugebauer R, Schwartz E, Perret C, Castelli F, Barnett ED, et al. Illness in children after international travel: Analysis from the GeoSentinel Surveillance Network. Pediatrics. 2010 May;125(5):e1072-80.

(60) Hunziker T, Berger C, Staubli G, Tschopp A, Weber R, Nadal D, et al. Profile of travel-associated illness in children, Zurich, Switzerland. J Travel Med. 2012;19(3):158-162.

(61) Crockett M, Hui C, Kuhn S, Ford-Jones L, Grondin D, Keystone J. Travel-related illnesses among pediatric VFRs in Canada. American Society of Tropical Medicine and Hygiene 60th Annual Meeting Dec. 4 - 8, 2011;Philadelphia, PA, USA(No. 968).

(62) Committee to Advise on Tropical Medicine and Travel. The Immunocompromised Traveller. Can Commun Dis Rep 2007;33(ACS-4):1-24.

(63) Committee to Advise on Tropical Medicine and Travel. Statement on Older Travellers. Can Commun Dis Rep. 2011;37(ACS-2):1-24.

(64) Committee to Advise on Tropical Medicine and Travel. Statement on Personal Protective Measures to Prevent Arthropod Bites. Can Commun Dis Rep. 2012;38(ASC-3):1-18.

(65) Public Health Agency of Canada. Canadian immunization guide. Cat.: HP40-3/2014E ed. Ottawa (ON): Public Health Agency of Canada; 2014.

(66) World Health Organization [Internet]. Hepatitis B, countries or areas at risk. 2012. http://gamapserver.who.int/mapLibrary/Files/Maps/Global_HepB_ITHRiskMap.png.

(67) World Bank [Internet]. South Asia. 2014 http://www.worldbank.org/en/region/sar. 